\title{
Relationships between children's behaviour and parents' work within families of mining and energy workers
}

\author{
Keith Robinson ${ }^{1}$ \\ David Peetz ${ }^{2}$ \\ Georgina Murray ${ }^{3}$ \\ Sonya Griffin ${ }^{4}$ \\ Olav Muurlink ${ }^{5}$
}

1 Griffith University, School of Humanities, Languages and Social Sciences, Australia

2 Griffith University, Department of Employment Relations and Human Resources, Australia

3 Griffith University, School of Humanities, Languages and Social Sciences, Australia

4 Griffith University, School of Humanities, Languages and Social Sciences, Australia

5 Central Queensland University, School of Business and Law, Australia

\begin{abstract}
Published in:
Robinson, K, Griffin, S, Peetz, D, Murray G \& Muurlink, O, 'The relationships between children's behavior and aspects of work, safety and wellbeing within families of mine and energy workers', Journal of Sociology, 53(2), 2016, pp 557-576, DOI: 10.1177/1440783316674357
\end{abstract}

Note: the officially published version described above should be cited for page number purposes. However, some readers might find the tables in this version easier to read (as per the top paragraph on page 9 of this version).

\begin{abstract}
We examine the relationships between the working arrangements of mineworkers and behavioural issues in their children, using a large Australian matched-pair dataset of workers and their partners. The findings suggest both that workers' work conditions, and aspects of safety and security, influence aspects of child behaviour, reflecting not least the results of tiredness, emotional exhaustion and sleep interruption. In addition, it appears that child behaviour probably influences the pressure experienced by their parents and hence their attitudes towards aspects of work.
\end{abstract}

\section{Keywords}

age groups, children, fly-in fly-out, long-distance commute workers, shift-work, sleep, well-being 


\section{Relationships between children's behaviour and parents' work within families of mining and energy workers}

Attempts to analyse the influences on well-being of children of workers in the mining and resources sectors have either been of limited scope or characterised by small sample sizes. So different studies have produced conflicting outcomes. This article provides findings from a large study - the Australian Coal and Energy Survey (ACES). It clarifies many earlier findings that lacked unequivocal data and establishes some new findings. We investigate whether psychological well-being or misbehaviour among children of mining and energy workers are associated with particular circumstances relating to their (mine and energy worker) parents' say in their job, physical insecurity and sleep interruptions.

\section{Background}

The mining and energy sector contains a mixture of workers living in local communities near mines ('local workers'), and long-distance commute (LDC) workers engaged mainly in either fly-in-fly-out (FIFO) or drive-in-drive-out (DIDO) practices. This reflects the growing impact of market liberal policies ('neoliberalism') on workplaces in the industry, in which management has sought to increase:

the rate of surplus value [which] depend[s] on the proportion between that part of the working day necessary to reproduce the value of the labouring power and the surplus time or surplus labour performed for the capitalist. It will, therefore, depend on the ratio in which the working day is prolonged over and above that extent. (Marx, 1865)

The new context has allowed employers to initiate work regimes that increase the working hours of workers to increase the former's surplus value or profit and, in doing so, have further alienated them from the creative tasks associated with work (Yadav and Nagle, 2012). Specifically, since the 1990s, mining companies have avoided the costs of establishing and supporting towns and community-based infrastructure, turning increasingly to LDC workers (Houghton, 1993). Many existing mines contain a mixture of local and LDC workers (Carrington and Pereira, 2011), and new remote mines have been entirely LDC-based. The existence of LDC workers has enabled, and been enabled by, the development of insecure contractor workforces and a move to rotating 12-hour shifts. Even some new mines near existing communities have used LDC-only models (Haxton, 2015), perhaps not so much due to direct costs as to the increased difficulty it poses for worker organisation. While some research has examined the impact of work arrangements on miners and their families, it has been mostly characterised by low participant numbers, especially in the research into children of affected families (e.g. Gallegos, 2005). Most studies conducted in other countries such as the US (Hendryx, 2015; Woolley et al., 2015) highlight an urgent need for further research, particularly in the areas addressing family and children's welfare (Blackman et 
al., 2014; Kaczmarek and Sibbel, 2008; Meredith et al., 2014; Torkington et al., 2011).

We are interested in what these new patterns in the conditions of work mean for the children of workers - in particular, the impact on children of aspects of shift arrangements in mining and energy, regardless of whether the workers concerned are on LDC arrangements. Our prior, qualitative investigations revealed that, even for local workers, the impact of rotating 12-hour shifts on family life can have many similarities to that of LDC - for the period of the roster while the employee is 'working', they effectively abandon their parental roles, as they spend most of their time either at work, commuting, eating or sleeping. Some partners may move from a mining community to a coastal town, changing from a 'local' partner to an LDC partner, because of low spousal involvement in household activity (Murray and Peetz, 2010). While many LDC workers make a conscious decision to choose the FIFO lifestyle with its rotating shifts (Gallegos, 2005; Sibbel, 2010), many local workers had rotating shifts thrust upon them by changes in enterprise agreements, awards or managerial practices. So the literature on both shift-work in general and FIFO in particular is relevant to our study.

Several existing sets of literature suggest relationships between: shift arrangements and the well-being of workers; shift arrangements and the wellbeing of parents, partners of workers or personal relationships between workers and their partners; working parental behaviour and child behaviour; and, least commonly, between shift arrangements and child behaviour. Our review of the literature focuses on these four strands. While some studies have made use of large datasets such as the Longitudinal Study of Australian Children (LSAC), these have not contained sufficient parental work-related variables to address the key questions here. Children's behaviour is not unidimensional but comprised of a number of related but distinct phenomena, not all of which need be affected in the same way by parental work arrangements. There is little research considering impacts in the opposite direction - that is, from children's behaviour to work-related attitudes of their parents.

The relationship between shift arrangements and the well-being of shiftworker-parents is the area probably most heavily researched of those listed above (e.g. Shen and Dicker, 2008) because the two are closely linked logically and empirical research is most convenient. For example, Johnson's (1997) study of 270 service workers found rotating shift-workers experienced greater work-family conflict and time management difficulties than day workers. Mott et al. 1965 (cited in Akerstedt et al. 1984: 409) found shift-work 'often' led to 'social isolation' and inability to fulfil normal social roles, while later Mylek and Schirmer (2015) found rotating shifts plus long hours negatively affected forestry workers' psychological-emotional and physical well-being.

Some published studies, especially on remote work, have been very small, for example, Carter and Kaczmarek's (2009) study of 10 offshore FIFO workers 
focusing on the challenges of FIFO lifestyle, self-identity and relationships. Pirotta (2009) looked at 20 female FIFO workers. Sibbel (2010) surveyed 90 FIFO mining employees and found they were within normal ranges for psychological well-being, while a more in-depth qualitative analysis of 16 such interviewees found they made 'purposeful and informed choices' to work. Voysey's (2012) study of FIFO workers found that roster satisfaction, roster length, relationship quality, children and perceived stress were all factors that determined workers' levels of stress. In a study into workers' perceptions of FIFO work, a key factor in dissatisfaction and stress with FIFO work was extensive periods away from home and families (Blackman et al., 2014: 195).

The relationship between shift arrangements and the well-being of partners of workers or families is less commonly researched, though an increasing number of studies have either collected (mostly qualitative) data from partners or asked workers their perceptions on partner effects. Handy's (2010) qualitative research, into the impacts of shift-work on 27 families in a New Zealand petrochemical plant, highlighted the trade-off women often make in sacrificing their own careers and financial security for a partner who does tightly structured and inflexible shift-work. Family interactions often revolved around the shift-working parent, requiring adjustment by other family members, leading to disruption and sometimes their isolation. Houghton (1993: 286) documented 'increased stress among spouses [who are] burdened with additional responsibilities in day-to-day decision making', with the onus placed on the spouse to adjust. Sibbel (2010), in contrast, found no differences on a range of matters between 32 partners of mining FIFO workers and their employed spouses.

The impact of shift arrangements on personal relationships between workers and their partners is a related but a more specific area. A US longitudinal study found working fixed nights substantially increased the probability of divorce, for both male and female workers (Presser, 2000). Taylor and Simmonds (2009), studying 63 FIFO workers, found most of the responsibility for managing the home and children was carried by the partner, though they mostly saw advantages outweighing costs. In Shen and Dicker's (2008) study there was a consensus among the 14 worker participants 'that shift-work placed relationships under stress and resulted in many [marriage] break-ups' (2008: 399). Nonetheless, workers acknowledged the advantages of extra income and time off during the week, although working weekends made social relationships difficult.

Skinner and Pocock (2008) found from a national survey of over 3000 people that work overload was the strongest predictor of work-life conflict, while work hours, their fit with preferences and control over work scheduling also related to a lesser degree to work-life conflict. A study of 750 Italian nurses, many of them shift-workers (Camerino et al., 2010), found different schedules had different impacts, some adverse, on work-family conflict. Bull's (1999) qualitative research into the effects of mobility on those in the Australian Defence Force (ADF) revealed civilian partners experience higher levels of 
stress due to the forfeiture of the control of their lifestyle caused by the frequent changes of community.

An analysis of the LSAC indicated flexibility for employees (being able to change start and finish times) led to 'better health, less difficulties, better coping, less distress, less work-family strain, less arguments and being less rushed' (Baxter et al., 2007: 84). Conversely, negative well-being was experienced by fathers working weekends, who reported 'slightly more conflict with their partners' (Baxter et al., 2007: 85), while working evenings and nights was associated with less family time, more family stress and feeling timepressured and rushed.

A small qualitative study (of 11 current or former LDC workers) in remote Queensland found FIFO workers reported higher levels of sleep disturbance, disruption of domestic activities and increased family pressures (Torkington et al., 2011). An airport-based survey, of 485 north Queensland FIFO workers, found 'the impact FIFO has on their private life' was an explicit reason for many forecasting they would leave in under a year (Blackman et al., 2014: 191). Yet research into 1697 FIFO workers in the Norwegian petroleum industry found shift-work resulted in few social or family life problems, and that an increase in leisure time could be a positive feature; critically, though, it observed that higher worker control was associated positively with all dependent variables (Ljoså and Lau, 2009). Employee strain due to difficulties with sleep cycles, depression, stress and anxiety has also been discussed in a review by Vojnovic et al. (2014), indicating that FIFO had both positive and negative effects on home life.

The relationship between parental behaviour and child behaviour is fairly extensively researched. Evidence is available, for example, to suggest that parental support during the adolescent phase of childhood protects against the development of mental health issues (Wille et al., 2008). Flouri and Buchanan (2003), in a large UK survey, found that father involvement positively related to educational and occupational mobility in children, child happiness and life satisfaction, while absence of fathers was linked to increased risks for children. Cookston and Finlay (2006), using the National Longitudinal Study of Adolescent Health, also found that the father's involvement was an important predictor of possible depression and behavioural problems in adolescents. Flouri's (2005: 181) book argued that father involvement was negatively associated with severe child behaviour problems and positively related to life satisfaction and happiness.

The relationship between shift arrangements and child behaviour is an area less well researched, and often not directly testing the work arrangements we are considering here in a remote context. Kaczmarek and Sibbel's (2008) comparative study into the well-being of three groups of children, using maternal perceptions, found that home partners experienced loneliness and hardship in coping with disruptions to social life, though some anticipated differences in indicators were not found - perhaps because each group only 
had 30 cells in it. It was 'speculated that protective mechanisms had evolved for the at-home parent' (Kaczmarek and Sibbel, 2008: 308), albeit accompanied by high maternal stress.

Han and Miller (2009) used a large US youth survey to find a relationship between parental work schedules and adolescent depression. Bradbury's (2011) study of 48 children found that paternal absence through FIFO resulted in the need for family re-adjustment and created problems for children. Dockery et al. (2009), using a subset of HILDA (the Household, Income and Labour Dynamics in Australia survey), found negative impacts of parents working nonstandard hours upon adolescent well-being, especially within sole-parent families. Strazdins et al. (2004; 2006), using large-scale Canadian data, found that children of parents working non-standard schedules were more likely to have social and emotional difficulties, though this was partially mediated through parental well-being. Shreffler et al. (2011) studied firefighter fathers and found that working over 60 hours per week was associated with lower satisfaction with children's behaviour. Li et al. (2014) reviewed 23 empirical studies and found significant associations between non-standard work schedules and adverse child developmental outcome, especially where parents worked full time.

The limited research into the influence of the LDC lifestyle on children inconclusively suggests evidence of both positive and negative effects. The 2014 Child Family Community Australia (CFCA) review into the effects of FIFO practices on children and family relationships also found 'a lack of depth and breadth of current peer-reviewed evidence regarding the effects on children and family relationships' (Meredith et al., 2014: 10), and spoke of a pressing need for further research. Likewise, the 2013 House of Representatives Standing Committee on Regional Australia inquiry report (HRSCRA, 2013) concluded that anecdotal evidence and lack of research into FIFO work practices only served to highlight the extreme limitations of the existing research.

Key aspects of the CFCA review suggested that the potential impacts on children would include: negative emotions; increased levels of behavioural problems when the parent is away for longer periods; greater experience of bullying at school; and greater pressure on children from the 'at-home' parent who is challenged with being the sole provider of the physical, emotional and intellectual needs of the children. We cannot cover all these aspects in our study, but we can address a number of the gaps in the literature. In particular, we ask: in what circumstances are instances of psychological problems and misbehaviour evident among children of mining and energy workers?

\section{Methodology}

Our primary data are the first wave of the Australian Coal and Energy Survey (ACES). The survey was completed towards the end of 2011. We had approximately 4500 respondents of whom 2639 were mining and energy 
workers belonging to the Construction, Forestry, Mining and Energy Union (CFMEU), a response rate of $28 \%$ among those we contacted from membership lists. We also surveyed respondents' partners (wives, husbands or de factos), and obtained 1961 respondents, 1798 of whom we matched to specific workers. We achieved a response rate of $78 \%$ among eligible partners in households where the mineworker completed a survey. Respondents were first contacted via telephone to ascertain a willingness to participate. Partners' details were recorded and the appropriate questionnaires were mailed to respondents. In the text below, to avoid confusion, when the partners are referring to their partners (that is, the mineworkers themselves), we use the term 'spouses' to refer to them (that is, a 'spouse' is a mineworker), and this word is substituted in tables where the original question asked partners a question concerning their partners.

To the knowledge of the authors, the large sample size makes this the largest couple-level study of its type. It comprised a 16-page self-completion questionnaire for the mining and energy workers (referred to hereafter as 'mineworkers', although about $10 \%$ of them were employed not in mines but elsewhere, mainly in power generation or the oil or chemical industry), complemented by a 12-page questionnaire for partners. Both questionnaires contained elements of: the Standard Shiftwork Index (SSI) (Tucker and Knowles, 2008) measuring psychological and physiological well-being of mineworkers and their partners; the Horne and Östberg morningnesseveningness questionnaire (Adan and Almirall, 1991); HILDA (Watson and Wooden, 2002); the Australian Work and Life Index (Pocock and Skinner, 2009); and indexes used by Allan et al. (2007), Gutek et al. (1991) and the World Values Survey (European Values Study Group and World Values Survey Association, 2006) among others. Goodman's (1997a) Strengths and Difficulties Questionnaire (SDQ) assessed psychological and physiological well-being of respondents' children. Goodman et al. (2000) produced an algorithm that predicted common forms of psychopathology using these 25 SDQ questions and suggested that diagnostic predictions from these questionnaires would be more accurate if they incorporated information from multiple informants.

ACES uses both worker and partner observations on child behaviour but was unable to include data taken directly from the young people. Notwithstanding this, the diagnostic predictions generated by the SDQ are likely to be more accurate when based on multiple informants (Goodman, 1997b), as in ACES. Goodman's SDQ has been constructed by compiling five distinct scales, each in turn based on five questions, relating to one of: hyperactivity, emotional symptoms, conduct problems, peer-related problems and pro-social skills. Details of the coding, as per the SDQ, are set out in Appendix A. A higher score on each of the first four scales (hyperactivity, emotional symptoms, conduct problems, peer-related) indicates greater behavioural problems by reference to those concepts; a higher score on the fifth scale (pro-social) implies lesser behavioural problems in terms of that concept. Analysis was undertaken using SPSS. 
We are cautious of the potential effects of common method variance - in effect, spurious correlation caused by using the same method and the same respondent to measure variables (Chang et al., 2010). Where only the mineworker's data suggests a correlation between variable $X$ and that respondent's perception of child behaviour, then it is possible that common method variance is at work, and/or that the mineworker's perception of variable $X$ is influenced by their own perception of the child's behaviour. However, where the mineworker and partner agree, and the partner's data also suggests a correlation between variable $X$ and the (partner's perception of) child behaviour, then common method variance is not an issue, and it is more likely there is a real relationship between variable $X$ and the behaviour of the child. Goodman et al. (2000) argue that estimates of child behaviour are more likely to be accurate where both partners agree.

As data analysed here are cross-sectional rather than longitudinal, it is difficult to prove the direction of causality: are parents' workplace situations influencing the behaviour of children (e.g. through greater parental absence or tiredness affecting children's behaviour), or is children's behaviour influencing the survey responses of their parents (e.g. parents believe they are not doing 'enough' of something because of certain behaviours in their children)? Hence the analysis below of significant correlations reflects our sociologically informed consideration of the likely pathways (Hassall and McDonald, 2005), that is: whether parental characteristics were likely to be influencing child behaviour (what we call principally 'downward causality', that is, from parent to child, through factors such as parental stress; C. Baxter et al., 2000); alternatively, whether a correlation is the result of children's circumstances influencing parental behaviour (what we call principally 'upward causality', that is from child to adult); or whether, as highlighted by J. Baxter et al. (2007), influence was plausibly fairly strong in both directions (what we call 'dual causality').

In the text we sometimes use the phrase 'strongly significant' to indicate where the significance of the correlation is better than 1\% (indicated by ** in text and tables), and 'very strongly significant' when it is better than $0.1 \%$ (indicated by ${ }^{* * *}$ ). That said, significance is not everything. In most of the correlations between various characteristics and mineworkers' assessment of child behaviour, the $N$ is over 1100 , while in most of the correlations between various characteristics and partners' assessment of child behaviour, the $\mathrm{N}$ is over 800. Accordingly, the significance of the former correlations consistently tends to be stronger than the significance of the latter correlations, even when $r$ is the same. Hence attention is also focused on the effect size - the size of the correlation, $r$ - not just the significance, in comparing correlations.

There are three substantive tables. Each shows, in the main data columns, the correlations of various items with each of the five aspects of children's behaviour in the SDQ, as measured first by the mineworker's assessment of the child's behaviour and then by the partner's assessment of the child's behaviour. We are most interested in those findings where there is some degree of similarity between the two correlations of an item: with the 
mineworker's, and then with the partner's, assessment of the child's behaviour. In the rows we see the various items that may influence child behaviour (via downward causality) or be influenced by it (via upward causality). As these are correlations in a cross-sectional dataset, we do not seek to use the data to prove the direction of causality. Those items in the rows may come from either the mineworker's questionnaire or the partner's questionnaire. The latter is always indicated by shading. The most leftward cell of each row also indicates which respondent is responsible for the information provided. Where we show closely related items from both the mineworkers' and partners' surveys, we pair them visually and use italic font to indicate that link.

We focused on whether children's social behavioural or psychological problems will be higher where the mining and energy parent: has little or no say over their working conditions; feels they are 'at risk' in their job; has a job that interferes with the family routine; or has interrupted sleep patterns. Each of these issues relates to ways in which work in the mining and energy industry may contribute to social behavioural problems or psychological issues among children. The preceding literature points to several ways in which problems with child behaviour might be related to aspects of shift-work. Accordingly, when we refer to the 'predicted' directions of relationships below, we are referring to predictions that various behavioural problems will be associated with one or more aspects of their mineworker parent's job, in terms of either lower say, higher uncertainty, higher perceived interference between work and life, or poorer sleep as per theorisations mentioned earlier.

\section{Findings}

Worker control regarding conditions of employment was positively associated with children's behaviour. In the first data row of Table 1, the partners' assessments of children's behaviour on the hyperactive, conduct and prosocial scales were significantly related to mineworkers' own perceived say. On all five scales there were correlations in the predicted direction between mineworker control over time off and each parent's assessments of child behaviour. On all but the hyperactivity scale, the magnitude of the correlations was similar for mineworkers' and partners' assessments, though significance varied.

Correlations with mineworker job satisfaction were all in the predicted direction (second data row of Table 1), but with significance achieved in only 5 of the 10 possible cells. On emotional problems, both parents' assessments of child behaviour significantly correlated with mineworker job satisfaction; on peer problems neither did.

The third to seventh data rows concern correlations with various indicators of working time problems and their interference with home life, based on five questions in the mineworkers' survey. All five measures of mineworker working time problems correlated strongly and significantly with all four mineworker 
Table 1: Correlations between work-related matters and parental perceptions of children's behaviour

\begin{tabular}{|c|c|c|c|c|c|c|c|c|c|c|c|}
\hline & & \multicolumn{2}{|c|}{ Hyperactive } & \multicolumn{2}{|c|}{ Peer problems } & \multicolumn{2}{|c|}{ Emotional } & \multicolumn{2}{|l|}{ Conduct } & \multicolumn{2}{|c|}{ Pro-social } \\
\hline & & $\mathrm{M}$ & $\mathrm{P}$ & $\mathrm{M}$ & $\mathrm{P}$ & $\mathrm{M}$ & $\mathrm{P}$ & $M$ & $\mathrm{P}$ & $\mathrm{M}$ & $\mathrm{P}$ \\
\hline $\begin{array}{l}\text { Mineworker's } \\
\text { view } \\
\text { Mineworker's } \\
\text { view }\end{array}$ & $\begin{array}{l}\text { M1. [no say over] when I } \\
\text { have time off from work. } \\
\text { M2.I am satisfied with the } \\
\text { kind of work I do in this } \\
\text { job. }\end{array}$ & $\begin{array}{l}-.027 \\
-.072 *\end{array}$ & $\begin{array}{l}-.074^{*} \\
-.010\end{array}$ & $\begin{array}{l}-.072^{*} \\
-.052^{\#}\end{array}$ & $\begin{array}{l}-.061^{\#} \\
-.047\end{array}$ & $\begin{array}{l}-.074^{*} \\
-.072^{*}\end{array}$ & $\begin{array}{l}-.055 \\
-.084^{*}\end{array}$ & $\begin{array}{l}-.115^{\star \star *} \\
-.087^{\star *}\end{array}$ & $\begin{array}{l}-.093^{\star \star} \\
-.064^{\#}\end{array}$ & $\begin{array}{l}.076 * \\
.058 *\end{array}$ & $\begin{array}{l}.082 * * \\
030\end{array}$ \\
\hline $\begin{array}{l}\text { Mineworker's } \\
\text { view }\end{array}$ & $\begin{array}{l}\text { M3. My current working } \\
\text { hours do not allow } \\
\text { enough time at home. }\end{array}$ & $.108^{* \star *}$ & $.077^{*}$ & $.090^{* *}$ & .027 & $.128 * * *$ & $.066^{\#}$ & $.108^{* \star *}$ & $.072^{*}$ & -.019 & -.040 \\
\hline $\begin{array}{l}\text { Partner's } \\
\text { view }\end{array}$ & $\begin{array}{l}\text { P1. My spouse's working } \\
\text { hours allow them enough } \\
\text { time at home. }\end{array}$ & $-.082^{*}$ & $-.099 *$ & $-.073^{*}$ & -.033 & $-.087^{*}$ & $-.076^{*}$ & $-.128^{* \star *}$ & $-.082^{* *}$ & .025 & $-.078^{* *}$ \\
\hline $\begin{array}{l}\text { Mineworker's } \\
\text { view } \\
\text { Mineworker's } \\
\text { view }\end{array}$ & $\begin{array}{l}\text { M4. My current working } \\
\text { hours are a source of } \\
\text { complaint. } \\
\text { M5. After work I come } \\
\text { home too tired to do } \\
\text { some of the things l'd like } \\
\text { to do. }\end{array}$ & $.115^{\star * \star}$ & $.072^{*}$ & $.106^{\star * *}$ & .037 & $\begin{array}{l}.128^{* \star *} \\
.141^{* * *}\end{array}$ & $.064^{\#}$ & $\begin{array}{l}.107 * * * \\
.080 * *\end{array}$ & $.068^{*}$ & $\begin{array}{l}-.032 \\
-.020\end{array}$ & $\begin{array}{l}-.079 * \\
-.064^{\#}\end{array}$ \\
\hline $\begin{array}{l}\text { Mineworker's } \\
\text { view }\end{array}$ & $\begin{array}{l}\text { M6. Time I work means I } \\
\text { can't fully participate in } \\
\text { household activities. }\end{array}$ & $.108^{* * *}$ & $.059^{\#}$ & $.121^{* * *}$ & .046 & $.179_{* \star \star}$ & $.059^{\#}$ & $.127^{* * *}$ & $.082 *$ & $-.065 *$ & $-.098 * *$ \\
\hline $\begin{array}{l}\text { Partner's } \\
\text { view }\end{array}$ & $\begin{array}{l}\text { P3. The time my spouse } \\
\text { devotes to work keeps } \\
\text { them from participating in } \\
\text { household activities. }\end{array}$ & .025 & $.070^{*}$ & $.084^{\star *}$ & $.084^{*}$ & .027 & $.092^{\star *}$ & .023 & .058 & $.076^{*}$ & -.024 \\
\hline $\begin{array}{l}\text { Mineworker's } \\
\text { view }\end{array}$ & $\begin{array}{l}\text { M7. I'm often so } \\
\text { emotionally drained when } \\
\text { I get home I can't } \\
\text { contribute to the family. }\end{array}$ & $.109 * * \star$ & $.057^{\#}$ & $.158^{\star \star \star}$ & $.091^{* *}$ & $.174^{\star \star \star}$ & $.076^{*}$ & $.116^{\star \star *}$ & $.107^{* *}$ & -.046 & -.038 \\
\hline
\end{tabular}




\begin{tabular}{|c|c|c|c|c|c|c|c|c|c|c|c|}
\hline $\begin{array}{l}\text { Partner's } \\
\text { view }\end{array}$ & $\begin{array}{l}\text { P4. My spouse is so } \\
\text { emotionally drained when } \\
\text { they get home they can't } \\
\text { contribute to the family. }\end{array}$ & .038 & .052 & $.073^{*}$ & $.069 *$ & $.103^{\star \star *}$ & $.102^{* * *}$ & .044 & .058 & $-.069 *$ & -.024 \\
\hline $\begin{array}{l}\text { Partner's } \\
\text { view } \\
\text { Partner's } \\
\text { view }\end{array}$ & $\begin{array}{l}\text { P2. My spouse's working } \\
\text { hours interfere with } \\
\text { community connections. } \\
\text { P5. My spouse's work } \\
\text { responsibilities affect my } \\
\text { own social life. }\end{array}$ & .067 & .018 & .026 & $.066^{*}$ & .056 & $\begin{array}{l}.071^{*} \\
.134^{\star * *}\end{array}$ & $.105^{\star \star \star}$ & $\begin{array}{l}.071^{*} \\
.065^{\star}\end{array}$ & .008 & $\begin{array}{l}-.051 \\
-.064\end{array}$ \\
\hline
\end{tabular}

$\mathbf{M}=$ correlation with members' assessment of child behaviour.

$\mathbf{P}=$ correlation with partner's assessment of child behaviour.

$\mathrm{N}=1123-56$ (member correlations), 819-59 (partner correlations).

$* \star *$ = significant at $0.1 \%$ level.

$* *=$ significant at $1 \%$ level.

* = significant at $5 \%$ level.

${ }^{\#}=$ weakly significant (at $10 \%$ level). 
assessments of negative child behaviour. For example, as the worker's level of agreement with the statement 'My current working hours do not allow enough time at home' increases, the level of hyperactivity increases. All partner assessments of child behaviour also correlated in the same direction with mineworker working time problems, but the correlations were generally smaller and often not significant. Still, partner assessments of child conduct problems correlated negatively and significantly with all five of these mineworker working time problem measures, signifying downward causality. On partner assessment of emotional problems, there were significant or weakly significant correlations with all measures of mineworker working time problems, and on partner assessment of hyperactivity this was the case for four of the five measures of mineworker working time problems. These differences suggest some upward causality also: it seems child behavioural problems (especially in relation to poor conduct) led mineworkers to feel they should be spending more time at home, especially but not only where the mineworker perceived those behavioural problems.

Partners' views on mineworker involvement in household or family activities are also shown in Table 1 (as items P3 and P4, analogous to M7 and M8 from the mineworkers' survey). The patterns were quite consistent with those from the mineworkers' survey, especially on the question of mineworkers being emotionally drained. That is, where both the mineworker and the partner reported that the mineworker came home too emotionally drained to contribute to the family, children's emotional problems and peer problems were worse, whether measured by the partner's or the mineworker's assessment of child behaviour.

Similarly, regardless of whether it was the mineworker or the partner who said that the mineworker's hours do not allow them enough time at home, such views were correlated with child emotional problems, conduct problems and perceived hyperactivity as measured by either partner or mineworker responses. In addition, it was these questions and those below, rather than whether a mineworker was an LDC or local worker, that explained differences in child behaviour outcomes.

To summarise: emotional problems in children appeared worse when their mineworker parents were too emotionally drained to take part in home activities, and worked excessive hours. Second, peer problems in children also appeared worse where mineworker parents were too emotionally drained to take part in home activities, and worked excessive hours. Third, hyperactivity appeared worse where mineworker parents worked what were, in their view, excessive hours. We emphasise that we do not conclude that these were the only relationships at play: there were other significant relationships, and even relationships that were non-significant had the predicted sign. But those we emphasise appear to be the strongest and most consistent relationships. It seems likely, though this is not proven in the data, that both downward and 
upward causality are at work here, with child behavioural problems (especially in relation to poor conduct) leading mineworkers to feel they should be spending more time at home, especially but not only where the mineworker perceives behavioural problems.

The relationship between trust and safety-related variables and children's behaviour is shown in Table 2. Several things stand out. First, mineworkers' perception of safety in the area where they sleep was adversely associated with child emotional problems as assessed by either parent. This is hard to explain as upward causality (i.e. as children influencing adult responses). The same applies to another phenomenon: anxiety about the mineworker's safety being on night shift, whether reported by the mineworker or the partner, was again adversely linked to emotional problems in the child, measured by either parent. Both these make sense as downward causality: anxiety by either parent could plausibly be translated into emotional problems for the child, but need not be so strongly related to other child behavioural difficulties. Our third observation is that all the coefficients on the four pathological measures had signs in the direction predicted, so even though many were not statistically significant we are again hesitant to rule out relationships between other aspects of safety perceptions and child behaviour, but if they did exist it appears that the ones we focus on were the most consistent.

Earlier results suggest that parental tiredness, and by implication sleep issues, may be important in understanding child behavioural problems. This is also suggested by the literature canvassed above. Sleep patterns are often related to the shift schedule a worker is given. There were correlations between the overall sleep index (comprising 15 items) and whether respondents work night shift $\left(r=.059^{*}\right)$ and their shift variability $\left(r=.089^{\star}\right)$, and very strong correlations with outcomes such as whether respondents feel too tired after work to do some things they would like or need to do $\left(r=-.47^{\star \star}\right)$, too emotionally drained to contribute to the family $\left(r=-.45^{\star \star}\right)$, or feel that work interferes with responsibilities outside work $\left(r=-.32^{\star \star}\right)$, interferes with their community connections $\left(r=-.37^{\star}\right)$, or keeps them from spending time with family or friends $\left(r=-.35^{\star \star}\right)$. We therefore directly measured respondents' assessment of aspects of their sleep. We used both individual items for mineworkers and scales comprising three or four items, plus the summary scale of 15 items. For their partners, we used single-item summary questions. For reasons of space and for comparability, in Table 3 we show those individual items for mineworkers where correlations were significant, plus all the scales, and comparable partner responses. The principal findings from Table 3, which compares aspects of parental sleep patterns with child behaviour, are that parental sleep difficulties appeared most strongly linked to conduct and emotional problems among children. While not all individual items correlated with these two forms of child behaviour problems, the sleep scales for mineworkers typically did, as mostly did the summary items for partners. The questions here were asked about the respondents' own sleep patterns, so the implication is that sleep disruption to either parent had some adverse consequences for child behaviour. For conduct problems, the partner's sleep 
appeared to be the more important (correlations appeared stronger with partner measures estimated in terms of difficulty falling asleep, how respondents feel about the amount of sleep they have, and how respondents feel in the first half hour after they awaken), perhaps reflecting the greater role the partner had in childrearing in families where one member is on rotating shift-work. However, this pattern was not so apparent in other measures of child behaviour, for which both parents' sleep mattered.

Importantly, the correlations were mostly significant with both mineworkers' and partners' ratings of child behaviour. Child peer problems correlated less consistently with some parental sleep problems, though (as assessed both by mineworkers and partners) peer problems significantly correlated with various measures asking mineworkers 'How well do you sleep?'. This relationship between child behaviour and parental sleep had been alluded to by Flouri and Buchanan (2003) and concurred with the findings of Meredith et al. (2014), highlighting school bullying in a wider context of neoliberal-driven family anxiety (Davies and Robinson, 2013) where parents worked harder and for longer hours. 
Table 2: Correlations between safety-related matters and parental perceptions of children's behaviour

\begin{tabular}{|c|c|c|c|c|c|c|c|c|c|c|}
\hline & \multicolumn{2}{|c|}{ Hyperactive } & \multicolumn{4}{|c|}{ Peer problems Emotional } & \multicolumn{2}{|c|}{ Conduct } & \multicolumn{2}{|c|}{ Pro-social } \\
\hline & $\mathrm{M}$ & $\mathrm{P}$ & $\mathrm{M}$ & $P$ & $\mathrm{M}$ & $P$ & $\mathrm{M}$ & $P$ & $\mathrm{M}$ & $P$ \\
\hline Mineworker's viewM1. Do you feel unsafe while working on night shifts? & .022 & .013 & .046 & .011 & $.138 * * *$ & $.080^{*}$ & .062 & .053 & .024 & .030 \\
\hline P2. Does your partner working night shifts make you feel anxious? & .026 & $.092^{* *}$ & .015 & .016 & $.086^{*}$ & $.085^{*}$ & $.090 *$ & $.072 *$ & .005 & .020 \\
\hline P1. Does partner being away at night make you anxious? & .022 & $.113^{\star \star}$ & .019 & .023 & .056 & $.107^{* \star}$ & $.084^{*}$ & $.086^{*}$ & -.041 & -.034 \\
\hline Mineworker's viewM2. Do you feel unsafe with the attitudes of fellow workers? & $.098^{\star *}$ & .050 & $.081^{* *}$ & .024 & $.110 * * *$ & .006 & $.087^{* *}$ & .029 & .018 & -.034 \\
\hline $\begin{array}{l}\text { Mineworker's viewM3. Do you feel unsafe due to the awareness of fatigue in fellow } \\
\text { workers? }\end{array}$ & .047 & .023 & $.139 * * *$ & .058 & $.139 * * *$ & $.070^{*}$ & $.080 * *$ & .049 & $-.061^{*}$ & .018 \\
\hline Mineworker's viewM4. Do you feel unsafe at the district where you sleep? & .029 & .036 & $.098^{* *}$ & .040 & $.124^{\star * *}$ & $.140 * * *$ & .060 & .046 & .012 & .019 \\
\hline
\end{tabular}

$\mathbf{M}=$ correlation with members' assessment of child behaviour.

$\mathbf{P}=$ correlation with partner's assessment of child behaviour.

$\mathrm{N}=1123-56$ (member correlations), 819-59 (partner correlations).

*** = significant at $0.1 \%$ level.

** = significant at $1 \%$ level.

* = significant at 5\% level.

\# = weakly significant (at $10 \%$ level). 
Table 3: Correlations between sleep-related matters and parental perceptions of children's behaviour

\begin{tabular}{|c|c|c|c|c|c|c|c|c|c|c|c|}
\hline & & \multicolumn{2}{|c|}{ Hyperactive } & \multicolumn{2}{|c|}{ Peer problems } & \multicolumn{2}{|c|}{ Emotional } & \multicolumn{2}{|l|}{ Conduct } & \multicolumn{2}{|c|}{ Pro-social } \\
\hline & & M & $\mathrm{P}$ & M & $\mathrm{P}$ & M & $\mathrm{P}$ & M & $\mathrm{P}$ & M & $\mathrm{P}$ \\
\hline Mineworker's view & M1. Do have difficulty sleeping between daytime shifts? & .052 & $.074^{\#}$ & $.131^{\star \star *}$ & .047 & $.141^{\star \star *}$ & $.129 * * *$ & $.071^{* \star}$ & $.108^{\star \star \star}$ & .003 & -.008 \\
\hline Mineworker's view & Scale - difficulty falling asleep (4 items) & .050 & .059 & $.114^{\star *}$ & .039 & $.170^{\star *}$ & $.123^{\star *}$ & $.066^{\#}$ & .065 & -.017 & .003 \\
\hline Partner's view & P1. Do you have difficulty falling asleep? & .011 & .039 & .024 & $.074^{*}$ & .054 & $.114^{\star * *}$ & $.131^{\star \star *}$ & $.110^{\star \star *}$ & -.020 & -.041 \\
\hline Mineworker's view & M2. Do you feel tired between day shifts? & $.079 *$ & $.077^{*}$ & $.085^{\star *}$ & $.100^{\star \star *}$ & $.133^{\star * *}$ & $.118^{\star \star *}$ & $.066^{*}$ & $.111^{\star \star *}$ & -.025 & -.042 \\
\hline Mineworker's view & M3. Do you feel tired between days off? & $.067^{*}$ & .039 & $.057^{\#}$ & $.069^{\#}$ & $.086^{\star *}$ & $.075^{\star}$ & $.065^{\star \star}$ & $.097^{\star *}$ & -.014 & .017 \\
\hline Mineworker's view & Scale - tiredness (3 items) & $.091^{\star *}$ & 0.057 & $0.062^{\#}$ & $0.067^{\#}$ & $.131^{\star *}$ & $.108^{\star *}$ & $.072^{\star}$ & $.088^{\star}$ & -0.039 & -0.001 \\
\hline Mineworker's view & M4. How well do you sleep between daytime shifts? & -.049 & -.001 & $-.147^{* * *}$ & $-.098^{*}$ & $-.150^{\star \star *}$ & $-.148^{\star \star \star}$ & $-.073^{*}$ & $-.072^{*}$ & -.012 & .000 \\
\hline Mineworker's view & $\begin{array}{l}\text { M5. How well do you sleep between successive nights } \\
\text { off? }\end{array}$ & -.050 & -.002 & $-.109 * \star \star$ & $-.094^{*}$ & $-.111^{\star \star \star}$ & $-.107^{\star \star \star}$ & $-.084^{\star \star}$ & $-.109 * \star \star$ & .013 & -.028 \\
\hline Mineworker's view & M6. How well do you sleep between successive days off? & $-.060^{\#}$ & .011 & $-.067^{*}$ & $-.059^{\star}$ & $-.081^{*}$ & $-.085^{*}$ & $-.061^{\#}$ & $-.064^{\#}$ & .020 & .002 \\
\hline Mineworker's view & Scale - how well you sleep (4 items) & -.051 & .001 & $-.083^{*}$ & $-.082^{*}$ & $-.155^{\star \star}$ & $-.113^{\star \star}$ & $-.113^{\star *}$ & $-.110^{\star *}$ & -0.001 & -.04 \\
\hline Partner's view & P2. How well do you normally sleep? & -.011 & $-.087^{\star *}$ & -.023 & $-.127^{\star *}$ & $-.068^{*}$ & $-.175^{\star \star}$ & $-.090^{\star *}$ & $-.120^{\star \star \star}$ & $.072^{*}$ & .049 \\
\hline Member's view & $\begin{array}{l}\text { Scale - How feel about the amount of sleep you get ( } 4 \\
\text { items) }\end{array}$ & -.029 & .037 & -.016 & .003 & $-.118^{\star *}$ & -.031 & $-.080^{\star}$ & -.047 & .003 & -.031 \\
\hline Partner's view & $\begin{array}{l}\text { P3. How do you feel about the amount of sleep you } \\
\text { normally get? }\end{array}$ & -.048 & $-.107^{\star \star \star}$ & -.030 & $-.097^{\star *}$ & -.066 & $-.082^{*}$ & $-.136^{\star \star \star}$ & 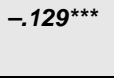 & $.089^{* *}$ & $.098^{* *}$ \\
\hline Mineworker's view & $\begin{array}{l}\text { M7. During the first half hour after you awake how do you } \\
\text { feel? }\end{array}$ & $-.082^{\star *}$ & .000 & -.039 & -.037 & $-.120^{\star \star *}$ & $-.063^{\#}$ & $-.092^{* *}$ & $-.088^{*}$ & .044 & .017 \\
\hline Partner's view & $\begin{array}{l}\text { P4. During first half hour after you awake how do you } \\
\text { feel? }\end{array}$ & $-.093^{\star \star}$ & 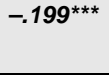 & -.027 & $-.116^{\star \star \star}$ & $-.078^{* *}$ & $-.117^{\star \star \star}$ & $-.116^{\star \star \star}$ & $-.154^{\star \star \star}$ & $.079^{* *}$ & $.089 * \star$ \\
\hline Mineworker's view & M8. Do you use alcohol to help you sleep? & $-.112^{\star *}$ & -.055 & -.039 & .016 & $-.077^{\star *}$ & .003 & $-.074^{*}$ & $-.069^{\star}$ & .040 & .060 \\
\hline Mineworker's view & Scale - all sleep variables (15 items excluding M8) & -.054 & -.047 & $-.080^{*}$ & -.057 & $-.147^{\star *}$ & $-.119^{\star *}$ & $-.079^{*}$ & $-.086^{*}$ & .011 & -.038 \\
\hline
\end{tabular}

$\mathbf{M}=$ correlation with members' assessment of child behaviour.

$\mathbf{P}=$ correlation with partner's assessment of child behaviour.

$\mathrm{N}=$ 843-1159 (member correlations), 662-839 (partner correlations). 
*** = significant at $0.1 \%$ level.

** = significant at $1 \%$ level.

* = significant at 5\% level.

\# = weakly significant (at $10 \%$ level). 


\section{Discussion and conclusions}

The results of this study were consistent with predictions regarding some workrelated matters in the market liberal context, particularly in regards to safetyrelated matters and sleep. Numerous correlations were significant, some were not, but almost all were in the predicted direction. When a worker had greater control regarding their conditions of employment there were significant correlations to children's behaviours in the predicted directions. Greater control likely reduced perceptions of alienation. Partners' belief that their spouses had greater control at work was linked to lower levels of negatively classified conduct and behaviour and higher levels of positive behaviours. Stresses experienced by children, measured by both parents' assessments of child behaviour, significantly correlated with mineworkers' work effects.

Safety concerns, both by mineworkers and manifested in partners' anxieties regarding the absence of their spouses, were also linked to child behaviour. While some of the work variables discussed above (e.g. whether respondents felt too tired or emotionally drained to do what they wanted) may partly reflect upward causality (child misbehaviour could make parents feel more guilty), this is unlikely to influence perceptions of safety at work. Our sleep data also substantiated much of what has hitherto been recorded as anecdotal evidence. Sleep deprivation and interrupted sleep patterns correlated with child behavioural problems. Sleep, or lack of sleep, determines the amount of time spent in social interaction, is a contributing factor to lapses in safety matters at work and is crucial to a functional marital relationship. The strain employees experience with difficult, forced sleep cycles is also linked to depression, stress and anxiety. This article revealed very strong indications of parental sleep disturbance as relating to deviant behaviour among workers' children. A significant correlation between sleep patterns and children's conduct (which included measures of school bullying and poor social skills) was confirmed.

Several conclusions follow. Children's behaviour is not a single or simple phenomenon, but one with several distinct components. There is, though, a consistent trend. Certain work characteristics - arising from rotating 12-hour shifts - lead to some workers being tired, emotionally drained, sleep-deprived, fearful for their safety or feeling they do not have enough opportunity to spend time doing things they wish to do, and these are then associated with adverse behavioural outcomes among children. However, the results are not of consistent magnitude or significance across all aspects of child behaviour. Instances of misbehaviour among children of mineworkers were higher where: those workers have little or no say over their working conditions; they and/or their partners feel the worker is at risk in their job; or either parent has interrupted sleep patterns. Different aspects of mineworker and partner work and life appear to affect different aspects of child behaviour.

The strongest and most consistent impact of work appears to be on emotional problems in child behaviour, and to a lesser extent on peer and conduct problems. There is less systematic evidence of impacts on hyperactivity or on (reducing) pro-social behaviour. 
It is also plausible that there is an impact in the opposite direction - that adverse children's behaviour increases the likelihood that workers in effect feel guilty about or aware of difficulties arising from their work.

Much of the public discussion of late has been about the impact of FIFO on workers, their families and communities. We do not address here the effect that work has upon communities; clearly the impact of LDC on a mining community is going to be quite different to that of having a predominantly local workforce (Haxton, 2015). However, to the extent that debate has focused on FIFO's relationship to the well-being of workers' families, we would add that some related (but not identical) considerations also apply to families affected by the rotating 12-hour shift regimes that characterise both LDC and non-LDC work. In both LDC and non-LDC households where workers are on long, rotating shifts, the burden of child-care falls mainly upon the partner, and if the partner is themselves having difficulty, there can also be adverse consequences for the child, especially evidenced in conduct problems. If workers feel tired, drained or distracted by long, rotating shifts then the effects may not be all that different between LDC and non-LDC workers on long, rotating shifts.

\section{Funding statement}

Funding for this research was provided by the Australian Research Council under its Linkage Program (Grant No LP0990766) in conjunction with the Mining and Energy Division of the Construction, Forestry, Mining and Energy Union. 


\section{Appendix A}

The variables in the SDQ scales were coded:

$1=$ Not true

$2=$ Somewhat true

$3=$ Certainly true

The scales were:

\section{Hyperactivity:}

+ Restless, overactive, cannot stay still for long

+ Constantly fidgeting or squirming

+ Easily distracted, concentration wanders

- Thinks things out before acting

- Sees tasks through to the end, good attention span

\section{Emotional Symptoms:}

+ Often complains of headaches, stomach-ache or sickness

+ Many worries, often seems worried

+ Often unhappy, down-hearted or tearful

+ Nervous or clingy in new situations, easily loses confidence

+ Many fears, easily scared

\section{Conduct Problems:}

+ Often has temper tantrums or hot tempers

- Generally obedient, usually does what adults request

+ Often fights with other children or bullies them

+ Often lies or cheats

+ Steals from home, school or elsewhere

\section{Peer Problems:}

+ Rather solitary, tends to play alone

- Has at least one good friend

- Generally liked by other children

+ Picked on or bullied by other children

+ Gets on better with adults than with other children

\section{Pro-social:}

+ Considerate of other people's feelings

+ Shares readily with other children (treats, toys, pencils, etc.)

+ Helpful if someone is hurt, upset or feeling ill

+ Kind to younger children

+ Often volunteers to help others (parents, teachers, other children) 


\section{References}

Adan, A. and H. Almirall (1991) 'Horne \& Östberg Morningness-Eveningness Questionnaire: A Reduced Scale', Personality and Individual Differences 12(3): $241-$ 53.

Akerstedt, T., A. Knutsson, L. Alfredsson and T. Theorell (1984) 'Shift Work and Cardiovascular Disease', Scandaniavian Journal of Work, Environment and Health 10(6): 409-14.

Allan, C., R. Loudoun and D. Peetz (2007) 'Influences on Work/Non-work Conflict', Journal of Sociology 43(3): 219-39.

Baxter C., R.A. Cummins and L. Yiolitis (2000) 'Parental Stress Attributed to Family Members with and without Disability: A Longitudinal Study', Journal of Intellectual and Developmental Disability 25(2): 105-18.

Baxter, J., M. Gray, M. Alexander et al. (2007) Mothers and Fathers with Young Children: Paid Employment, Caring and Wellbeing, Social Policy Research Paper 30. Canberra: FaHCSIA.

Blackman, A., R. Welters, L. Murphy, L. Eagle, M. Pearce, J. Pryce et al. (2014) 'Workers' Perceptions of FIFO Work in North Queensland, Australia', Australian Bulletin of Labour 40(2): 180-200.

Bradbury, S.G. (2011) Children and the Fly-in/ Fly-out Lifestyle: Employment-related Paternal Absence and the Implications for Children, PhD thesis, Curtin University, Perth.

Bull, D. (1999) 'Mobility: What Effect Does It Have on ADF Personnel?', Australian Defence Force Journal 138: 31-7.

Camerino, D., M. Sandri, S. Sartori et al. (2010) 'Shiftwork, Work-Family Conflict among Italian Nurses, and Prevention Efficacy', Chronobiology International 27: 1105-23.

Carrington, K. and M. Pereira (2011) 'Assessing the Social Impacts of the Resources Boom on Rural Communities', Rural Society 21(1): 2-20.

Carter, T. and E. Kaczmarek (2009) 'An Exploration of Generation Y's Experiences of Offshore Fly-in/Fly-out Employment', Australian Community Psychologist 21(2): 5266.

Chang, S.-J., A. van Witteloostuijn and L. Eden (2010) 'From the Editors: Common Method Variance in International Business Research', Journal of International Business Studies 41: 178-84.

Cookston, J.T. and A.K. Finlay (2006) 'Father Involvement and Adolescent Adjustment: Longitudinal Findings from Add Health', Fathering 4: 137-58.

Davies, C. and K. Robinson (2013) 'Reconceptualising Family: Negotiating Sexuality in a Government Climate of Neoliberalism', Contemporary Issues in early Childhood 14: 
39-53. Dockery, A., L. Jianghong and G. Kendall (2009) 'Parents' Work Patterns and Adolescent Mental Health', Social Science \& Medicine 68: 689-98.

European Values Study Group and World Values Survey Association (2006) European and World Values Surveys: Four Wave Integrated Data File, 1981-2004, consulted September

2016:

http://www.icpsr.umich.edu/icpsrweb/ICPSR/studies/4531?geography=Canada?

Flouri, E. (2005) Fathering and Child Outcomes. Chichester: Wiley.

Flouri, E. and A. Buchanan (2003) 'The Role of Father Involvement and Mother Involvement in Adolescents' Psychological Well-being', British Journal of Social Work 33: 399-406.

Gallegos, D. (2005) Aeroplanes Always Come Back: Fly-in Fly-out Employment: Managing the Parenting Transitions', Murdoch, WA: Centre for Social and Community Research.

Goodman, R. (1997a) 'The Strengths and Difficulties Questionnaire: A Research Note', Journal of Child Psychology and Psychiatry 38: 581-6.

Goodman, R. (1997b) 'The Strengths and Difficulties Questionnaire: A Research Note', Journal of Child Psychology and Psychiatry 38: 581-6.

Goodman, R., D. Renfrew and M. Mullick (2000) 'Predicting Type of Psychiatric Disorder from Strengths and Difficulties Questionnaire (SDQ) Scores in Child Mental Health Clinics in London and Dhaka', European Child and Adolescent Psychiatry 9: 129-34.

Gutek, B.A., S. Searle and L. Klepa (1991) 'Rational versus Gender Role Explanations for Work-Family Conflict', Journal of Applied Psychology 76: 560-8.

Han, W.J. and D.P. Miller (2009) 'Parental Work Schedules and Adolescent Depression', Health Sociology Review 18: 36-49.

Handy, J. (2010) 'Maintaining Family Life Under Shiftwork Schedules: A Case Study of a New Zealand Petrochemical Plant', New Zealand Journal of Psychology 39: 29-37.

Hassall, R. and J. McDonald (2005) 'Parenting Stress in Mothers of Children with an Intellectual Disability: The Effects of Parental Cognitions in Relation to Child Characteristics and Family Support', Journal of Intellectual Disability Research 49: 405-18.

Haxton, N. (2015) 'FIFO Inquiry: 100pc Fly-in, Fly-out Mines Splitting Community', $A B C$ News 11 June.

Hendryx, M. (2015) 'The Public Health Impacts of Surface Coal Mining', Extractive Industries and Society 2: 820-6.

Houghton, D. (1993) 'Long-distance Commuting a New Approach to Mining in Australia', Geographical Journal 159: 281-91. 
HRSCRA (House of Representatives Standing Committee on Regional Australia) (2013) Inquiry into the Use of 'Fly-in, Fly-out' (FIFO) Workforce Practices in Regional Australia, (consulted 18 March 2015): http://www.aph.gov.au/Parliamentary_Business/Committees/ House_of_representatives_Committees?url=ra/fifodido/report.htm

Johnson, K.L. (1997) A Work and Family Perspective on the Effects of Shiftwork. <asters' thesis, Carleton University, Ottawa.

Kaczmarek, E.A. and A.M. Sibbel (2008) 'The Psychosocial Well-being of Children from Australian Military and Fly-in/Fly-out (FIFO) Mining Families', Community, Work \& Family 11: 297-312.

Li, J., S.E. Johnson, W.J. Han, S. Andrews, G. Kendall, L. Strazdins et al. (2014) 'Parents' Nonstandard Work Schedules and Child Well-being: A Critical Review of the Literature', Journal of Primary Prevention 35: 53-73.

Ljoså, C. and B. Lau (2009) 'Shiftwork in the Norwegian Petroleum Industry: Overcoming Difficulties with Family and Social Life - A Cross-sectional Study', Journal of Occupational Medicine and Toxicology 4: 22-32.

Marx, K. (1865) 'Value Price and Profit', in Economic Manuscripts, (consulted October 2016): https://www.marxists.org/archive/marx/works/1865/value-price-profit/ch02.htm

Meredith, V., P. Rush and E. Robinson (2014) 'Fly-in Fly-out Workforce Practices in Australia: The Effects on Children and Family Relationships', CFCA Paper 19. Melbourne: Australian Institute of Family Studies.

Murray, G. and D. Peetz (2010) Women of the Coal Rushes. Sydney: UNSW Press.

Mylek, M. and J. Schirmer (2015) 'Beyond Physical Health and Safety: Supporting the Wellbeing of Workers Employed in the Forest Industry', Forestry: An International Journal of Forest Research 88(4): 391-406.

Pirotta, J. (2009) 'An Exploration of the Experiences of Women Who FIFO', Australian Community Psychologist 21: 37-51.

Pocock, B. and N. Skinner (2009) The Australian Work and Life Index (AWALI). Adelaide: Centre for Work + Life, University of South Australia.

Presser, H. (2000) 'Non-standard Work Schedules and Marital Conflict', Journal of Marriage and the Family 62: 93-110.

Shen, J. and B. Dicker (2008) 'The Impacts of Shiftwork on Employees', International Journal of Human Resource Management 19: 392-405.

Shreffler, K.M., M.P. Meadows and K.D. Davis (2011) 'Fire Fighting and Fathering: Work-Family Conflict, Parenting Stress, and Satisfaction with Parenting and Child Behaviour', Fathering 9: 169-88.

Sibbel, A.M. (2010) Living FIFO: The Experiences and Psychosocial Wellbeing of Western Australian Fly-in/Fly-out Employees and Partners, D.Phil. thesis, Edith Cowan University, Perth. 
Skinner, N. and B. Pocock (2008) 'Work-Life Conflict: Is Work Time or Work Overload More Important?', Asia Pacific Journal of Human Resources 46: 303-15.

Strazdins, L., R. D'Souza, M. Clements et al. (2006) 'Unsociable Work? Non-standard Work Schedules: Family Relationships, and Children's Wellbeing', Journal of Marriage and Family 68: 394-410.

Strazdins, L., R.J. Korda, L.L. Lim, D.H. Broom and R. D'Souza (2004) 'Around the Clock: Parent Work Schedules and Children's Wellbeing in a 24-h Economy', Social Science \& Medicine 59: 1517-27.

Taylor, J.C. and J.G. Simmonds (2009) 'Family Stress and Coping in the Fly-in Fly-out Workforce', Australian Community Psychologist 21: 23-36.

Torkington, A., S. Larkins and T. Gupta (2011) 'The Psychosocial Impacts of Fly-in Flyout and Drive-in Drive-out Mining Employees: A Qualitative Study', Australian Journal of Rural Health 19: 135-41.

Tucker, P. and S.R. Knowles (2008) 'Review of Studies that Have Used the Standard Shiftwork Index: Evidence for the Underlying Model of Shiftwork and Health', Applied Ergonomics 39: 550-64.

Vojnovic, P., G. Michelson, D. Jackson et al. (2014) 'Adjustment, Well-being and Helpseeking: Among Australian FIFO Mining Employees', Australian Bulletin of Labour 40: 242-61.

Voysey, W. (2012) 'Satisfaction with a Fly-in/Fly-out (FIFO) Lifestyle: Is It Related to Rosters, Children and Support Resources Utilised by Australian Employees and Partners and Does It Impact on Relationship Quality and Stress? Thesis, Murdoch University, Perth.

Watson, N. and M. Wooden (2002) 'The Household, Income and Labour Dynamics in Australia (HILDA) Survey: Wave 1 Survey Methodology', HILDA Project Technical Paper Series No. 1/02. Melbourne Institute of Applied Economic and Social Research, University of Melbourne.

Wille, D.P.N., S. Bettge and U. Ravens-Sieberer (2008) 'Risk and Protective Factors for Children's and Adolescents' Mental Health: Results of the BELLA Study', European Child and Adolescent Psychiatry 17: 133-47.

Woolley, S., A. Youk, T. Bear, L.C. Balmert, E.O. Talbott and J.M. Buchanich (2015) 'Impact of Coal Mining on Self-rated Health among Appalachian Residents', Journal of Environmental and Public Health 2015.

Yadav, G.K. and Y.K. Nagle (2012) 'Work Alienation and Occupational Stress', Social Science International 28: 333-44.

\section{Biographical notes}


Keith Robinson received his BA double major in Sociology and History from Griffith University in 2015 and a First Class Honours in Political Science from the University of Queensland in 2016. He is currently a PhD candidate with Griffith University.

David Peetz is Professor of Employment Relations at Griffith University, in the Centre for Work, Organisation and Wellbeing. He once worked in the then Commonwealth Department of Industrial Relations, in its Senior Executive Service. He has been a consultant for the International Labour Organization and is on the Board of the Trade Union Education Foundation. He is the author of several books and a Fellow of the Academy of Social Sciences in Australia.

Georgina Murray is an adjunct associate professor at Griffith University. She teaches political economy and has published three books, the latest being Financial Elites and Transnational Business: Who Rules the World? (2012). Currently she is preparing two more books: Women at Work: Labor Segmentation and Regulation (with David Peetz) and Think Tanks and Global Politics: Key Spaces in the Structure of Power (with Alejandra Salas-Porras).

Sonya Griffin graduted from Griffith University in 2016 with a BA majoring in Sociology and History. She is currently studying Honours in the School of Humanities, Languages and Social Sciences at Griffith University.

Olav Muurlink is senior lecturer in HRM and strategic management at Central Queensland University. He has previously worked in manufacturing and media, including as a business owner. As a psychologist, he has worked as a consultant or researcher on projects for the British, New Zealand and Queensland governments. He is also chair of the management committee of the Bangladesh-Australian education charity 